\title{
EFFECTS OF DESENSITIZING AGENTS ON DENTINAL TUBULE OCCLUSION
}

\author{
EFEITOS DE AGENTES DESSENSIBILIZANTES NA OBLITERAÇÃO \\ DE TÚBULOS DENTINÁRIOS
}

\author{
César Augusto Galvão ARRAIS ${ }^{1}$, Daniel Chi Ngai CHAN², Marcelo GIANNINI ${ }^{3}$
}

1- Graduate student (PhD degree), Department of Restorative Dentistry, Piracicaba, SP, Brazil.

2- Associate Professor, Dept. Oral Rehabilitation School of Dentistry, Medical College of Georgia, Augusta, GA, USA

3- Assistant Professor, Department of Restorative Dentistry, Piracicaba Dental School, Campinas State University, Piracicaba, SP, Brazil.

Corresponding address: Marcelo Giannini - Faculdade de Odontologia de Piracicaba - UNICAMP - Área de Dentística - Departamento de Odontologia Restauradora - Av. Limeira, 901 - Areião - Piracicaba - SP - CEP 13414-018 - Phone: 19-34125340 - Fax: $19-34125218$ e-mail: giannini@fop.unicamp.br

Received: August 04, 2003 - Returned for modification: September 09, 2003 - Accepted: January 29, 2004

\begin{abstract}
$T$

1 he aim of this study was to evaluate the features of dentinal tubules occlusion following application of three commercially available desensitizing agents: potassium oxalate-based / Oxa-Gel (OX), HEMA and glutaraldehyde-based / Gluma Desensitizer (GD) and acidulated phosphate fluoride-based / Nupro Gel (AF). Buccal cervical areas of twenty-four extracted human third molars were smoothed and wet-polished with SiC papers and diamond pastes, in order to simulate the clinical aspect of hypersensitive dentin cervical surfaces. The teeth were randomly divided into four groups $(n=6)$, according to the dentin surface treatments: G1: untreated; G2: OX; G3: GD; G4: AF. Specimens were fractured in the lingual-buccal direction and prepared for SEM analysis. OX promoted tubule occlusion by crystal-like deposits in the lumen of the tubules. While GL created a thin layer over the dentin surface, AF application produced precipitates that occluded the tubules. According to the SEM analysis, all desensitizing agents were able to occlude the dentinal tubules.

UNITERMS: Dentin hypersensitivity; Desensitizing agents; Dentinal tubule occlusion.
\end{abstract}

\section{RESUMO}

O

objetivo deste estudo foi avaliar as características de obliteração dos túbulos dentinários de três agentes dessensibilizantes: produto a base de oxalato de potássio / Oxa-Gel (OX), produto a base de HEMA e glutaraldeído / Gluma Desensitizer (GD) e produto a base de flúor-fosfato acidulado / Nupro Gel (AF). A região vestibular e cervical de vinte e quatro terceiros molares humanos extraídos foi planificada e polida com lixas de SiC e pastas de diamante para simular superfícies vestibulares dentinárias cervicais com hipersensibilidade. Os dentes foram aleatoriamente divididos em quatro grupos ( $\mathrm{n}=6$ ), de acordo com os seguintes tratamentos superficiais da dentina: G1: sem tratamento; G2: OX; G3: GD; G4: AF. Os espécimes foram fraturados no sentido línguo-vestibular e preparados para microscopia eletrônica de varredura (MEV). OX promoveu oclusão pela deposição de cristais no interior dos túbulos. Enquanto, GL criou uma camada delgada sobre a superfície da dentina, a aplicação do AF produziu a formação de precipitados que ocluíram os túbulos. De acordo com a análise em MEV, todos agentes dessensibilizantes testados foram capazes de obliterar túbulos dentinários.

UNITERMOS: Hipersensibilidade dentinária; Agentes dessensibilizantes; Oclusão de túbulos dentinários.

\section{INTRODUCTION}

Previous studies have shown that hypersensitive areas may present exposed dentinal tubules ${ }^{2,21}$. The hydrodynamic theory assumes that a stimulus applied on the dentin surface causes movement of tubular fluid, which in turn activates mechanoreceptor nerves, eliciting pain and discomfort ${ }^{3}$.
According to this theory, if the functional radius of opened dentinal tubules decreases, then the permeability is also decreased, reducing dentin sensitivity. Thus, treatments for hypersensitivity should occlude dentinal tubules and prevent nerve sensitivity. Therefore, some products have been indicated to treat dentin hypersensitivity due to their ability to occlude tubules ${ }^{7}$. 
Dentinal tubules can be obliterated on the surface and/ or occluded within the tubule orifices. However, superficial occlusion of tubules can be removed by daily tooth brushing, dissolution of the precipitate promoted by saliva or consumption of acidic beverages, leading to short-term desensitizing effects ${ }^{8,10,19}$. Effective treatment with long-term results has been related to intratubular deposition, which reduces the fluid flow rate or totally seals the tubule lumen ${ }^{16}$.

Several previous studies have only assessed the effects of selected desensitizing agents on the dentin surface $e^{5,8,11}$, which do not support any evidence about the features of these products on tubule occlusion and as such does not determine their potential effectiveness in reducing hypersensitivity over time. Since several desensitizing agents have been shown to promote significant tubule occlusion in vitro, these may also have the ability to be clinically effective. Therefore, the purpose of this study was to evaluate the ability of three selected desensitizing agents on dentinal tubule occlusion and morphological tubule changes using scanning electron microscopy (SEM).

\section{MATERIALS AND METHODS}

The specimens were prepared from twenty-four freshly extracted sound human third molars stored in $10 \%$ formalin ( $\mathrm{pH}$ 7.0) at room temperature. The teeth were obtained after informed consent of the patients and under the protocol (38/2003) analyzed and approved by the Ethics Committee of Piracicaba Dental School / UNICAMP, Brazil. The teeth were cleaned of gross debris and placed in deionized water for twenty-four hours before beginning the experiment.

The teeth were sectioned in mesiodistal direction using a water-cooled diamond saw (Buehler Ltd.). From each buccal surface, a sectioned sample ( $5 \mathrm{~mm}$ length $\mathrm{x} 5 \mathrm{~mm}$ width $\mathrm{x} 3.5 \mathrm{~mm}$ depth) was obtained including the cervical area. Each fragment was ground (600-grit) flat on a polishing machine (APL4, Arotec) to remove enamel and expose the underlying dentin cervical area. The exposed dentin surfaces were wetpolished with 1000- and 1200-grit aluminum oxide abrasive paper and diamond pastes (6mm, 3mm, $1 \mathrm{~mm}$ and $1 / 4 \mathrm{~mm}$ ),

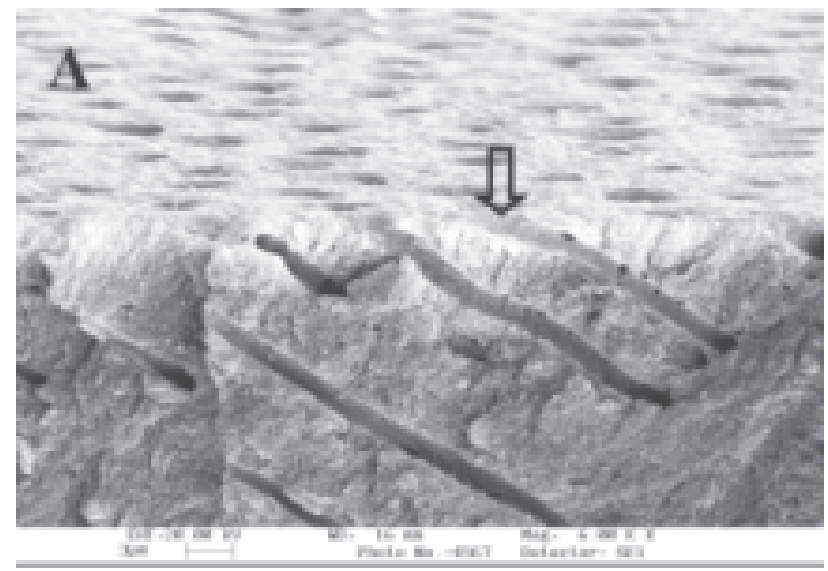

simulating dentin hypersensitivite in cervical regions. Specimens were ultrasonicated for $12 \mathrm{~min}$ and rinsed with deionized water.

The specimens were randomly assigned to four groups $(n=6)$, according to the dentin surface treatments followed, as recommended by the manufacturer's instructions:

Group 1- untreated surface (control).

Group 2- Oxa-Gel applied for 30s.

Group 3- Gluma Desensitizer applied for 30s.

Group 4- Nupro Gel applied for 4min.

Table 1 describes the composition of tested desensitizing agents. Specimens were fixed in Karnovisk solution for 1 hour and fractured with a sharp blade placed perpendicular to the buccal surface. Each fractured sample was sputter coated (MED 010, Balzers) with a thin gold layer and examined under SEM (VP 435, Leo). Photomicrographs of representative dentin surface areas were taken at magnification between 6,000x and 15,000x.

\section{RESULTS}

Photomicrographs for untreated, control group and desensitizing agents applied on dentin surface are shown in Figures 1 to 4. Examined untreated areas presented a smooth appearance and presented opened tubules orifices. Moreover, no smear layer covering dentin and no smear plugs closing tubules were observed (Figure 1a and 1b).

SEM observation of the selected desensitizing agents presented different modes of tubular occlusion. Figures 2A and $2 \mathrm{~B}$ are micrographs of dentinal surfaces treated with oxalate potassium-based desensitizing agent. Precipitation of oxalate crystals was observed within the tubules. Some crystals had approximately the same diameter of the tubules.

A thin layer of approximately $1 \mu \mathrm{m}$ thick was observed covering the treated surfaces with Gluma Desensitizer (Figure 3). The majority of dentinal tubules were obliterated with a coat that covered the surface and infiltrated into tubules as plugs. Figures 4A and 4B showed the fractured dentin surface treated with acidulated phosphate fluoride. Precipitates were observed closing most dentinal tubules;

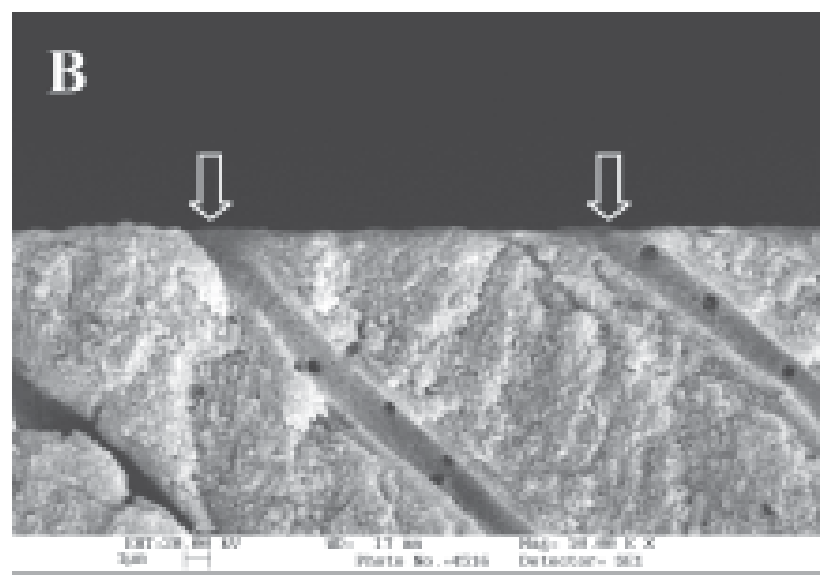

FIGURE 1- SEM micrograph of untreated dentin. No smear layer and smear plugs were observed. Open dentinal tubules are indicated by arrows. Lateral canals were seen in the tubule walls. (A: x 6,000; $\mathrm{B}$ : x 10,000) 
however, they were not attached to the tubules walls. A mild mineral removal of peritubular dentin was observed at the dentinal tubules entrance.

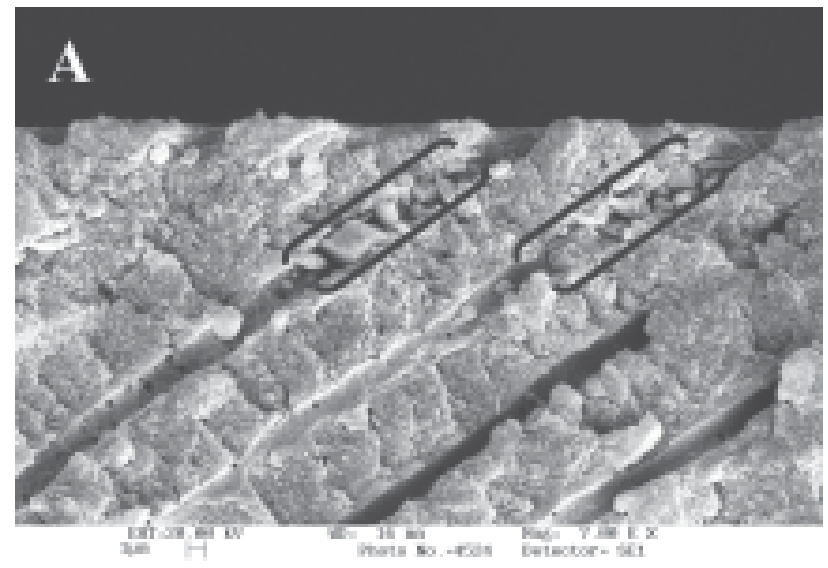

\section{DISCUSSION}

This study evaluated the occlusion of dentinal tubules by three desensitizing agents. The active ingredient of Oxagel, Desensitizer and Nupro Gel are potassium oxalate,

FIGURE 2- SEM micrograph of potassium oxalate-treated dentin. Note the crystal formation extending into the tubules. Areas between parentheses exhibit large formation of crystals within the dentin tubules. $(A$ and $B: \times 7,000)$
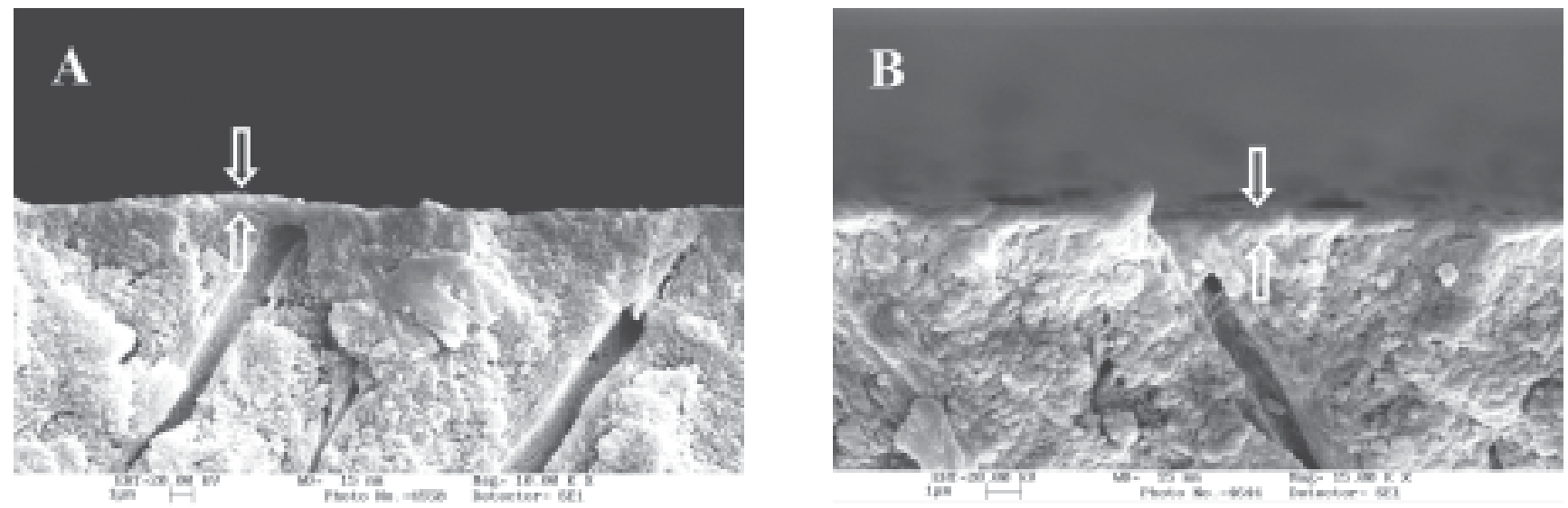

FIGURE 3- SEM micrograph of HEMA and glutaraldehyde-treated dentin. A thin layer can be seen over the dentin (between arrows), occluding the entrance of dentinal tubules. (A: x 10,000; B: x 15,000)
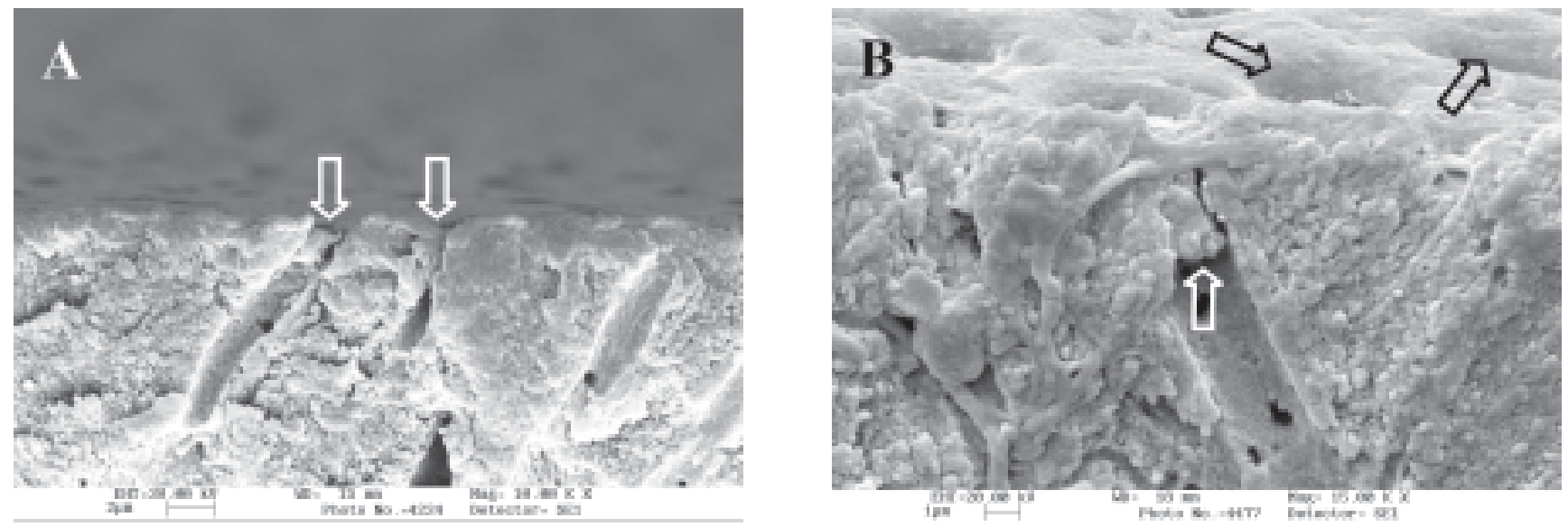

FIGURE 4- SEM micrograph of acidulated phosphate fluoride-treated dentin. Note the precipitates within the tubules and below the surface (white arrow), and the funnel shape dentinal tubules opening (black arrows). (A: x 10,000; $\mathrm{B}$ : x 15,000) 
2-hydroxyethyl methacrylate (HEMA) + glutaraldehyde and acidulated phosphate fluoride, respectively. Desensitizing agents occluded tubules by salt precipitation or resin deposition. Thus, if hypersensitivity is due, in part, to open dentinal tubules at the dentin surface, desensitizing agents that may promote a reduction in the number of opened tubules or in their diameter could, according to the hydrodynamic theory, reduce fluid movement within the tubules, which in turn would reduce dentin hypersensitivity.

Control group specimens that were polished and ultrasonicated in order to remove smear layer presented open tubules and tubule density (Figure 1) similar to those described for sensitive areas ${ }^{2,21}$. This technique applied to create artificial cervical sensitive areas does not use any chemical solution to remove the smear layer, which could alter the underlying dentin. Moreover, analysis of fractured specimens allowed verification of the simulated sensitive cervical areas for control group, intra-tubular precipitation and sub-superficial tubule occlusion for treated groups.

Dentin treated with potassium oxalate gel showed substantial crystal-like deposits within the tubule lumen (Figure 2). The gel was able to penetrate into the tubule and react with calcium ions from the dentin fluid to form insoluble calcium oxalate crystals, $6,7,16$. The precipitation occurred inside the dentinal tubules, extending up to $15-\mu \mathrm{m}$ depth and the crystal dimensions were varied, including crystals that occluded a large portion of the tubule diameters. Besides, the tubule occluding properties of potassium oxalate might be combined with the inhibitory property of potassium on intradental nerves ${ }^{15}$. This theory is based on the fact that the increased potassium ion concentration ([ $\left.\left[\mathrm{K}^{+}\right]\right)$ in the extracellular fluids into the tubules may cause a sustained depolarization of the nerves ${ }^{12}$. This will result in inactivation of action potential generation through a mechanism such as axonal accommodation ${ }^{1}$.

Gluma Desensitizer is an aqueous solution containing 5\% glutaraldehyde and 35\% HEMA. Because glutaraldehyde is a biological fixative, it has been suggested that the dentinal tubules are occluded as an effect of reaction with plasma proteins from dentinal fluid. Although studies displayed transverse septa in the lumen of dentinal tubules as a result of glutaraldehyde action ${ }^{9,18}$, no septum was observed in this study. The presence of a thin layer over treated dentin was noted penetrating and occluding dentinal tubules. The coat was up to $1-\mu \mathrm{m}$ thick and its composition was probably resinous. HEMA is a hydrophilic monomer compound of dentin bonding agents with ability to infiltrate into acidetched and moist dental hard tissues ${ }^{20}$.

Nupro Gel is a commercial product containing 1.23\% fluoride and $0.1 \mathrm{M}$ phosphoric acid. With the acidic property, the fluoride gel was able to etch peritubular dentin and form a funneled portion of the tubule at the dentin surface. Ionized calcium in the tubular fluid and that liberated during the acid attack react with the active ingredient of the gel, sodium fluoride. The raising of ionized calcium concentration exceeded the solubility product constant for calcium fluoride, precipitating on and within the tubules ${ }^{7}$. Even though calcium fluoride might occlude most dentinal tubules, its use as a desensitizing agent has been questioned due to its solubility in saliva ${ }^{13,17}$

This present SEM examination provided understanding of the potential occluding effect of three in-office desensitizing agents. The different mechanisms of dentinal tubules occlusion probably result in different effectiveness of hypersensitivity reduction (i.e. degrees of pain relief). However, the longevity of the precipitates or resins in dentinal tubules and their ability to resist acid challenge over time is unknown, although oxalate precipitates appear to wash out under challenge in the clinical environment ${ }^{16}$. Therefore, the clinical effectiveness of these materials will depend in part on the dissolution resistance or solubility level of precipitates or resins.

\section{CONCLUSION}

The results of the present study confirmed by SEM analysis of fractured dentin samples, demonstrated that OxaGel, Gluma Desensitizer and Nupro Gel were able to occlude dentinal tubules by different modes. However, further research is required to provide evidence of the durability of occlusion of these desensitizing agents under simulated clinical conditions together with functional studies designed to assess their ability to reduce fluid flow (hydraulic conductance) through dentin.

\section{ACKNOWLEDGEMENTS}

The authors are indebted to Dr. E.W. Kitajima (NAPMEPA/ESALQ-USP) for technical electron microscopy support. This study was supported by grants 00/08347-0, 01/13034-3 and 01/02771-7 from FAPESP, Brazil.

\section{REFERENCES}

1- Aidley DJ. The Physiology of Excitable Cells. Cambridge: Cambridge University Press; 1989.

2- Absi Eg, Addy M, Adams D. Dentin hypersensitivity. A study of the patency of dentinal tubules in sensitive and non-sensitive cervical dentine. J Clin Periodontol 1987; 14:280-4.

3- Brännström M, Linden LA, Aström A. The hydrodynamics of the dental tubule and pulp fluid: a discussion of its significance in relation to dentinal sensitivity. Caries Res 1967; 1:310-7.

4- Bruun C, Moe D, Madsen HE. Study on the dissolution behavior of calcium fluoride. Scand J Dent Res 1983; 91: 247-50.

5- Dijkman GE, Jongebloed WL, de Vries J, Ogaard B, Arends J. Closing of dentinal tubules by glutaraldehyde treatment, a scanning electron microscopy study. Scand J Dent Res 1994; 102:144-50.

6- Gillam DG, Mordan NJ, Sinodinou AD, Tang JY, Knowles JC, Gibson IR. The effects of oxalate-containing products on the exposed dentine surface: an SEM investigation. J Oral Rehabil 2001; 28:1037-44. 
7- Greenhill JD, Pashley DH. The effects of desensitizing agents on the hydraulic conductance of human dentin in vitro. J Dent Res 1981; 60: 686-98.

8- Kerns DG, Scheidt MJ, Pashley DH, Horner JA, Strong SL, Van Dyke TE. Dentinal tubule occlusion and root hypersensitivity. J Periodontol 1981; 62:421-8.

9- Kolker JL, Vargas MA, Armstrong SR, Dawson DV. Effect of Desensitizing Agents on Dentin Permeability and Dentin Tubule Occlusion. J Adhesive Dent 2002; 4: 211-21.

10- Kuroiwa M, Kodaka T, Kuroiwa M, Abe M. Dentin hypersensitivity. Occlusion of dentinal tubules by brushing with and without an abrasive dentifrice. J Periodontol 1994; 65:291-6.

11- Lan WH, Liu HC, Lin CP. The combined occluding effect of sodium fluoride varnish and Nd:YAG laser irradiation on human dentinal tubules. J Endod 1999; 25:424-6.

12- Markowitz K, Bilotto G, Kim S. Decreasing intradental nerve activity in the cat with potassium and divalent cations. Arch Oral Biol 1991; 36:1-7.

13- McCann HG. The solubility of fluorapatite and its relationship to that of calcium fluoride. Arch Oral Biol 1968; 13: 987-1001.

14- Pashley DH, Galloway SE. The effects of oxalate treatment on the smear layer of ground surfaces of human dentine. Arch Oral Biol 1985; 30: 731-7.

15- Pashley DH. Strategies for clinical evaluation of drugs and/or devices for the alleviation of hypersensitive dentin. In: Rowe NH, editor. Proceedings of Symposium on Hypersensitive Dentin. Oringin and Management. Ann Arbor: Univ Michigan; 1985. p.6588.

16- Pashley DH, Carvalho RM, Pereira JC, Villanueva R, Tay FR. The use of oxalate to reduce dentin permeability under adhesive restorations. Am J Dent 2001; 14:89-94.

17- Plagmann HC, Konig J, Bernimoulin JP, Rudhart AC, Deschner J. A clinical study comparing two high-fluoride dentifrices for the treatment of dentinal hypersensitivity. Quintessence Int 1997; 28: 403-8

18- Schupbach P, Lutz F, Finger WJ. Closing of dentinal tubules by Gluma desensitizer. Eur J Oral Sci 1997; 105:414-21.

19- Suge T, Ishikawa K, Kawasaki A. Effects of fluoride on the Calcium Phosphate precipitation method for dentinal tubule occlusion. J Dent Res 1995; 74:1079-85.

20- Swift Jr ED, Perdigao J, Heymann HO. Bonding to enamel and dentin: a brief history and state of the art. Quintessence Int 1995; 26:95-110.

21- Yoshiyama M, Masada J, Uchida A, Ishida H. Scanning electron microscopic characterization of sensitive vs. insensitive human radicular dentin. J Dent Res 1989; 68:1498-1502. 